\title{
DEVOLVER A IMAGEM: A FOTOGRAFIA COMO ATO ETNOGRÁFICO
}

\author{
ALEXSÂNDER NAKAÓKA ELIAS ${ }^{1}$
}

\begin{abstract}
RESUMO
A proposta deste artigo é demonstrar a centralidade da fotografia na pesquisa etnográfica realizada junto à escola budista Honmon Butsuryu-shu (HBS), de origem japonesa e presente no Brasil desde 1908. 0 intuito consiste em elucidar que 0 ato fotográfico, mais do que um mero instrumento de pesquisa, permeia a minha relação com a referida comunidade durante todas as inserções em campo, enfatizando a importância das imagens produzidas, tanto para 0 antropólogo quanto para 0 grupo estudado. Aqui, busco problematizar a noção de autoria e posse das fotografias, percebendo que tais imagens foram "construídas" (con)juntamente com a HBS em uma relação de coprodução, ressaltando, ainda, o seu poder (re)memorativo e a necessidade de "devolver a imagem".
\end{abstract}

\author{
Palavras-chave \\ Fotografia; Etnografia; Coprodução; Devolver a imagem; Memória
}

\section{RETURN THE IMAGE: THE PHOTOGRAPH AS AN ETHNOGRAPHIC ACT}

\begin{abstract}
The purpose of this article is to demonstrate the centrality of photography in my ethnographic research carried out in the Buddhist school Honmon Butsuryu-shu (HBS). A center of Japanese origin and present at Brazil since 1908. The aim is to elucidate that the photographic act permeated my relation to the community during all my fieldwork, emphasizing the importance of the images produced, both for the anthropologist and for the group studied. Here, I try to concentrate in the notion of authorship of the photographs, realizing that such images were "built" together with the HBS in a coproduction relation, emphasizing their memorial power and the need to "return the image".
\end{abstract}

\section{KEYWORDS \\ Photography; Ethnography; Coproduction; Return the image; Memory}

\section{RETOUR L'IMAGE: PHOTOGRAPHIE AVEC ACTE ETHNOGRAPHIQUE}

\section{RÉSUMÉ}

Le but de cet article est de démontrer le rôle central de la photographie dans la recherche ethnographique menée par moi dans l'école bouddhiste Honmon butsuryü-shu (HBS), d'origine japonaise, au Brésil depuis 1908. L'objectif c'est de préciser que l'acte photographique, plus qu'un instrument de recherche, s'est imprégné dans ma relation avec cette communauté dans le terrain de recherche, en insistant sur l'importance des images produites à la fois l'anthropologue et pour le groupe d'étude. Ma première préoccupation c'est d'analyser la notion d'auteur et la propriété des photographies, tout en se rendant compte que ces images ont été "construites" avec HBS dans un rapport de coproduction, soulignant également son pouvoir (re)mémoire et la nécessité de "retourner l'image".

\footnotetext{
${ }^{1}$ Doutorando em Antropologia Social pelo Departamento de Filosofia e Ciências Humanas (IFCH) da Unicamp, bolsista FAPESP.
} 


\section{MOTS-CLÉS}

Photographie; Ethnographie; Coproduction; Retourner l'image; Mémoire

\section{DEVOLUCIÓN DE LA IMAGEN: LA FOTOGRAFÍA COMO ACTO ETNOGRÁFICO}

\section{RESUMEN}

La propuesta de este artículo es demostrar la centralidad de la fotografía en la investigación etnográfica por mí realizada junto a la escuela budista Honmon Butsuryu-shu (HBS), de origen japonés y presente en Brasil desde 1908. El propósito consiste en elucidar que el acto fotográfico, más que un mero instrumento de investigación, permeó mi relación con la referida comunidad durante todas las inserciones en el campo, enfatizando la importancia de las imágenes producidas, tanto para el antropólogo cuanto para el grupo estudiado. En este sentido, busco problematizar la noción de autoría de las fotografías, percibiendo que tales imágenes fueron "construidas" junto con la HBS en una relación de coproducción, resaltando, aún, su poder (re)memorial y la necesidad de "devolver la imagen".

\section{PALABRAS CLAVE}

Fotografía; Etnografía; Coproducción; Devolver la imagen; Memoria 


\section{PRóloco}

No presente artigo, proponho uma análise sobre a pesquisa que realizo desde 2011 junto à primeira comunidade budista do Brasil, denominada Honmon Butsuryu-shu (HBS). Tal experiência se deu a partir da minha inserção em campo, sempre com uma máquina fotográfica nas mãos e com o auxílio de um importante interlocutor, o Correia Odoshi, um sacerdote com elevado grau hierárquico dentro da religião.

Dessa forma, as reflexões que compõem este trabalho surgiram após uma grande viagem realizada com a comunidade HBS do Brasil, entre os dias 03 e 23 de maio de 2014, com o intuito de acompanhar os sacerdotes e fiéis desta tradição budista japonesa. Este grupo realizou uma caravana pelos locais sagrados para a religião, passando por diversos templos no Japão (país de origem da HBS), Índia e Nepal, sendo os dois últimos países de suma importância histórica e mitológica para uma tradição budista mais ampla².

É fundamental destacar que esta excursão consistiu em uma peregrinação religiosa e turística, repleta de narrativas mitológicas sobre o Budismo, além de estar permeada pelos rituais realizados pela Honmon Butsuryu-shu em cada lugar sagrado para a religião. Esses fatores me incentivaram a realizar cerca de seis mil fotografias durante a caravana.

Além disso, ressalto que o convite para participar desta viagem foi feito ainda em meados de 2012, por Marcos Eduardo Purificação Correia, conhecido como Correia Odoshi. Como sacerdote de um nível hierárquico alto e ocupando, na época da viagem, o cargo de Arcebispo, que corresponde ao posto máximo de poder na HBS do Brasil, Correia pôde garantir e legitimar a minha participação como fotógrafo-antropólogo, mesmo não sendo um fiel convertido (termo êmico).

Assim, pretendo demonstrar que o ato fotográfico permeou a minha relação com a referida comunidade desde a primeira inserção em campo, enfatizando, neste caso, a importância das imagens produzidas, tanto para o antropólogo quanto para o grupo estudado. Aqui, busco tensionar a noção de autoria e posse das fotografias, percebendo que tais imagens foram "construídas" juntamente com a HBS em uma relação de coprodução, ressaltando a necessidade de "devolver a imagem", por conta do seu poder simbólico e (ге)memorativo.

\footnotetext{
${ }^{2}$ Existem três grandes vertentes budistas, que possuem em comum os seus mitos de origem, relacionados aos ensinamentos (conhecidos como "Sutras") do Buda Shakyamuni ou Buda Histórico, que nasceu em Lumbini (Nepal) e peregrinou pela Índia. Estas vertentes são: Theravada (ou "Caminho dos Anciões"), Vajrayana (ou "Caminho do Diamante") e Mahayana (ou "Grande Veículo"). A Honmon Butsuryu-shu é uma das diversas escolas do Budismo japonês que pertencem ao "Grande Veículo".
} 


\section{COMO TRATAR AS IMAGENS NA PESQUISA ANTROPOLÓGICA: UMA PRIMEIRA ESCOLHA}

Durante a pesquisa realizada (con)juntamente com a caravana da HBS do Brasil em 2014, produzi um amplo acervo de fotografias, além de um diário, notas e gravações de narrativas míticas, contadas, principalmente, pelo Correia Odoshi. Dessa forma, ao retornar da viagem, comecei o esboço de um texto preliminar, com o intuito de organizar, minimamente, os dados coletados nestas vivências.

Neste ponto, a questão da memória possibilitada pelo arquivo fotográfico já se mostrou fundamental para a composição do texto etnográfico. Ao retomar as anotações e áudios, uma espécie de (longo) bloqueio mental surgiu, não deixando a escrita fluir.

Com tal dificuldade, em determinado momento optei por rever as cerca de seis mil imagens fotográficas produzidas durante a peregrinação por Japão, Índia e Nepal, o que me levou, também, a revisitar as mais de quatro mil fotografias que havia realizado pelos templos e eventos religiosos da HBS no Brasil, um corpus que compôs a minha pesquisa de mestrado, iniciada em maio de 2011 e encerrada em 2013.

Assim, ao me debruçar mais lentamente sobre este extenso conjunto imagético, diversas questões e detalhes relativos à religião HBS - como os espaços, os rituais e as diversas relações encontradas - dali começaram a emergir, e foram, de forma gradativa, complementando os relatos gravados em áudio e os textos escritos no meu caderno de campo durante a peregrinação, me auxiliando a rememorar a experiência etnográfica.

Pude notar, por exemplo, que as fotografias "oficiais" em grupo, registradas em todos os templos e locais sagrados visitados, apresentavam uma repetição na composição dos espaços ocupados (na imagem), sendo que, em um núcleo principal, normalmente localizado no centro das fotografias e em primeiro plano, ficavam os sacerdotes e os fiéis mais graduados, próximos das suas esposas (chamadas de "okusans") e filhos. Isso significa que, além de uma composição embasada primariamente pela hierarquia dentro da religião, uma segunda função relacional, esta estabelecida por afinidade (pais, filhos, irmãos e/ou amigos ficavam próximos), ali se fazia presente.

Além de fazer notar questões hierárquicas, as fotografias (como a apresentada abaixo), pela capacidade que possuem de ativar tais memórias, serviram como fonte viva para perceber e rever os acontecimentos, gestos e posturas rituais, símbolos religiosos, composições dos espaços dos Hondos (locais onde são realizadas as cerimônias dentro dos Templos), vestimentas rituais e outras nuances, as quais, durante as experiências de campo, muitas vezes não tive o tempo necessário para me atentar. 


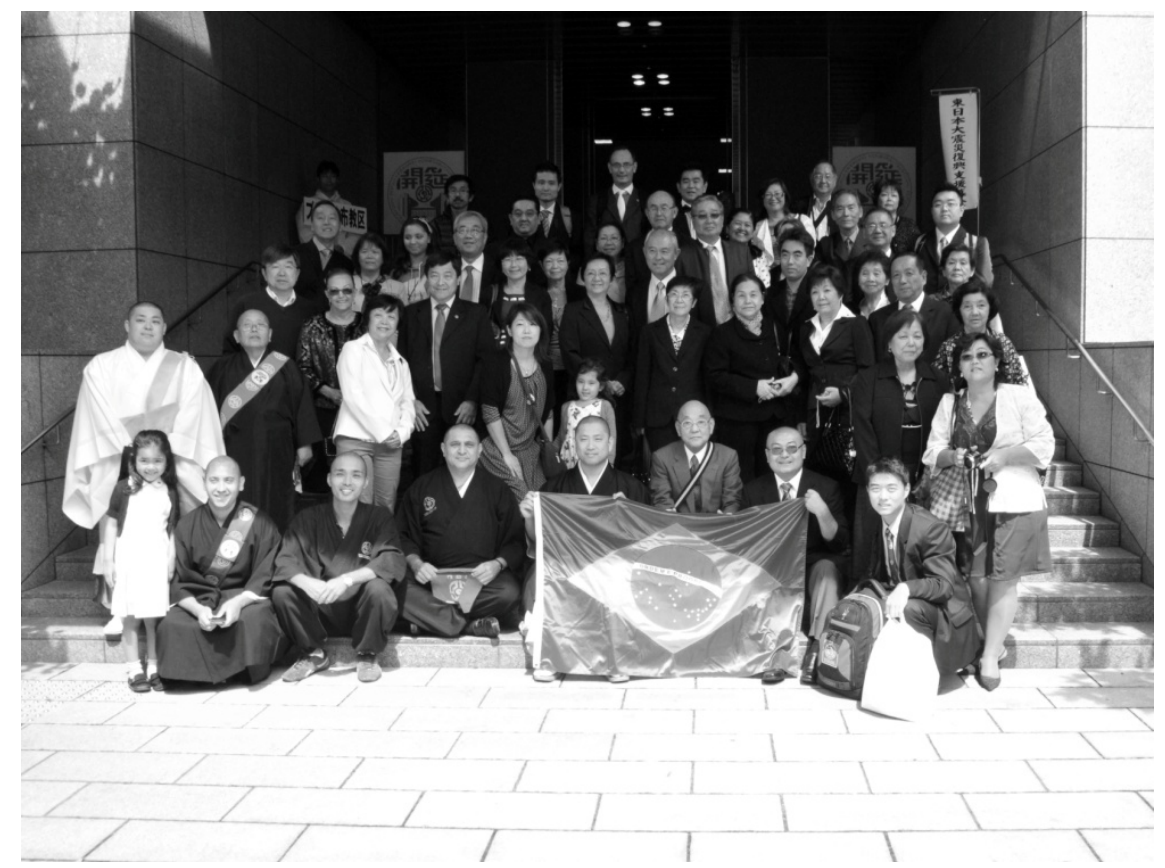

Imagem 01: Primeira fotografia em grupo, realizada na entrada do Hondo (nave) do Templo Seifuji, em Osaka, Japão. Os sacerdotes mais graduados estão em primeiro plano, no centro da imagem. Perto deles, podemos visualizar as okusans (esposas de sacerdotes) e seus filhos e filhas.

Também pude captar com as tomadas fotográficas a importância nuclear dos objetos sagrados da HBS, em especial da "Imagem e Escrita Sagrada, Namumyouhourenguekyou". Esta tensiona a própria noção e conceito de "imagem", já que é, ao mesmo tempo, uma escrita em kanji (ideograma japonês), uma imagem (pois chega até nós através da visão) e consiste, ainda, no Buda Primordial, uma espécie de divindade máxima para os adeptos da Honmon Butsuryu-shu, sem a qual não é permitido que nenhum ritual ou cerimônia seja realizada ${ }^{3}$.

Através da visualização cuidadosa das fotografias percebi, ainda, a presença quase constante do Correia Odoshi, o interlocutor privilegiado que me permitiu realizar a pesquisa. Ele me apresentou aos demais integrantes da comunidade como fotógrafo desde a primeira inserção em campo, na Catedral Nikkyoji (localizada na cidade de São Paulo) até a peregrinação por Japão, Índia e Nepal. Através dele, estabeleci uma malha (meshwork) de relações, no sentido que nos fala Ingold (2011; 2013; 2015), com os diversos integrantes da HBS do Brasil (como sacerdotes, fiéis e leigos), que foi essencial para a plena realização das várias etapas da etnografia.

\footnotetext{
${ }^{3}$ Neste caso, a Imagem Sagrada é mais do que a mera representação do Buda Primordial. Ela "é" o Buda Primordial, pois a divindade está ali contida. É possível afirmar, dessa forma, que tal imagem consiste em um objeto que possui agência, no sentido que nos fala Alfred Gell (1998).
} 


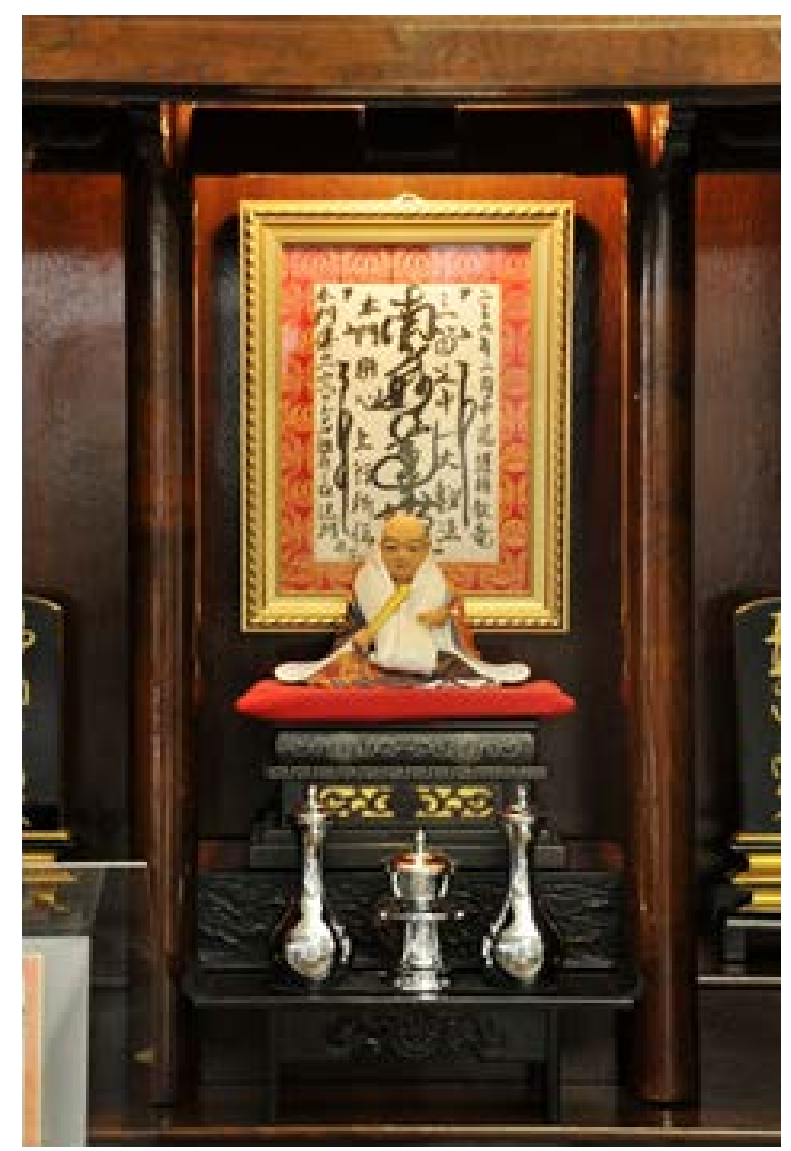

Fotografia 02: Imagem, escrita e oração sagrada,

Namumyou-hourenguekyou, ao fundo. A estátua

à frente de tal imagem é Nichiren Daibossatsu, um importante mestre budista japnês, precursor da HBS.

Assim, ressalto que após "fitar" completamente e com cuidado este longo acervo visual, comecei a elaborar associações a partir das imagens, que permitiram o insight inicial da escrita do texto antropológico. Isso me faz pensar, indo ao encontro do que afirma Samain (2012, p. 13), nas particularidades e relações possíveis entre o texto escrito e a imagem (particularmente a fotográfica), que possuem pelo menos dois desdobramentos epistemológicos sucessivos. O primeiro diz respeito aos problemas complexos das singularidades e complementaridades entre os diversos suportes da comunicação humana (som, imagens, fala, escrita, etc.) e o segundo remete às questões das interações entre um chamado "pensamento selvagem" (LÉVI-STRAUSS, 1962) e um "pensamento domesticado" pela escrita (GOODY, 1988).

Andrea Barbosa (2009, p. 71) caminha na mesma direção, ao considerar que o mundo consiste, ao mesmo tempo, em uma experiência sensorial, emocional e também reflexiva:

"[...] imagens que compõem o trabalho de campo se configuram tanto como modo de provocar como de expressar a pesquisa, situação que em alguns casos não seria possível somente com a escrita. Nessas situações, texto e imagens são absolutamente complementares, não por imaginar que o texto possa controlar a polissemia das imagens e por isso associar-se a elas em um caráter explicativo, mas por possibilitar 
entradas e construções diferentes dentro da temática trabalhada" (BARBOSA, 2009, p. 72).

Desta forma, Barbosa chama a atenção para o fato de que, com as imagens, abre-se uma nova possibilidade de construção de conhecimento, distinta da baseada exclusivamente no discurso verbal. Um conhecimento em que o silêncio, os olhares, os gestos e os movimentos possam ser, de fato, considerados elementos fundamentais na reflexão sobre as relações nas quais cria sentido.

Carlos Brandão é outro autor que, trabalhando na intersecção entre Antropologia e Arte, chama a atenção para o importante papel das imagens fotográficas em suas pesquisas e me serve de inspiração. Revela, ao falar dos seus trabalhos, que sempre viu a necessidade de voltar do campo com algo além de registros em cadernetas e entrevistas gravadas. "Еra preciso voltar repleto de imagens, de fotografias em cores e em branco-e-preto. Era preciso voltar de 'lá' com trezentas fotos, mesmo que no texto eu fosse usar treze, ou nenhuma" (2005, p. 160-161). Pensando em tais questionamentos, Brandão sugere a experiência de uma "antropoética", na qual o intuito seria o de gerar textos em que palavra e imagem se equilibram e procuram estabelecer, juntas, uma linguagem em dois tempos, sem que haja supremacia de uma "fala" sobre a outra.

Tendo como base tais reflexões, sugiro pensar de forma pormenorizada essa complementaridade entre visual e verbal, ressaltando a importância de levar as imagens a sério e propondo utilizar a fotografia como uma metodologia de pesquisa de campo, como fizeram, por exemplo, Margaret Mead e Gregory Bateson (1942) ${ }^{4}$, em uma tentativa de equilibrar tais forças e estabelecer uma complementaridade entre imagem e escrita.

Assim, tais eram (e ainda são) os meus questionamentos, no momento em que comecei a escavar as imagens fotográficas (re)colhidas no convívio com a comunidade HBS. Dessa maneira, sigo os passos de Samain (2005, p. 126-127), quando este, ao comparar o cinema com a fotografia, afirma que "assistimos a um filme, enquanto mergulhamos numa fotografia". Se por um lado tem-se um olhar horizontal (filme), por outro estamos diante de uma mirada "vertical, abissal", na qual escavamos como um arqueólogo.

Esta concepção de escavador das imagens, que também encontra morada nas reflexões de Ingold (2013), aponta para uma necessidade de reposicionar a antropologia e indica que os praticantes das artes podem sugerir novos caminhos, não confinando as suas pesquisas nos textos escritos, explorando, dessa forma, as relações entre percepção,

\footnotetext{
${ }^{4}$ Aqui, me refiro ao livro Balinese character: a photographic analysis (1942), considerado o marco da chamada "Antropologia Visual". Tal obra, realizada junto aos nativos da ilha de Bali, apresenta ao leitor 100 pranchas verbo-visuais, compostas de páginas duplas: de um lado ficavam os relatos de campo escritos por Maraget Mead e, do outro, conjuntos de fotografias realizadas por Gregory Bateson, em uma relação complementar e dialógica. Para uma análise da relação entre imagem e texto nesta obra, ver Samain, 2000.
} 
criatividade, habilidade e as fronteiras entre arqueologia e antropologia, pensando, neste sentido, as imagens fotográficas como um artefato a ser escavado.

\section{UMA RELIGIÃO QUE SE DÁ A VER}

Após assumir que as imagens são, para mim, esses pequenos sítios arqueológicos, que compõem uma "metodologia" de pesquisa de campo capaz de gerar importantes memórias, que precisam ser escavadas e analisadas de forma complementar aos relatos verbais (orais e escritos) coletados, principalmente, durante as experiências na peregrinação com a HBS, é necessário estabelecer um contraponto, ao pensar, de forma analítica, que tais imagens foram construídas exatamente nos nós das malhas relacionais com a comunidade estudada (INGOLD, 2011; 2013; 2015).

Neste caso, é fundamental assinalar o fato de a HBS do Brasil, através dos seus sacerdotes (que orientam os fiéis neste sentido), realiza um movimento explícito para se distinguir das demais correntes budistas no país. Tal comunidade busca expandir os preceitos do seu livro litúrgico sagrado, o Sutra Lótus Primordial, e da oração e imagem sagrada, Namumyouhourenguekyou.

Para isso, realiza no país um processo de adaptação sociocultural, incorporando, por exemplo, termos da língua local (pontífice, sumo pontífice, papa, Catedral, batismo, passeata, monge, bispo, sacerdote, etc.) e realizando cerimônias que são disponibilizadas publicamente, através de registros audiovisuais produzidos, muitas vezes, por fiéis e pelos próprios sacerdotes. Assim, utilizam fotografias e gravações videográficas, que posteriormente são disponibilizadas em sites com conteúdo próprio ${ }^{5}$ e na revista institucional "Lótus" (atualmente, com 123 edições), publicada em português.

Dessa forma, é possível pensar que as adaptações da HBS no Brasil através das cerimônias e rituais que mesclam os idiomas português e japonês; a incorporação de termos provenientes de uma cultura cristã; com a ênfase dada por sacerdotes e fiéis à assertiva "somos uma religião"6 e com o movimento para conseguir aumentar o número de adeptos, através das conversões, da "catequese budista", de "passeatas", "batismos budistas" e de caravanas como a que presenciei em 2014 (que acontecem trienalmente), estão diretamente

\footnotetext{
${ }^{5}$ Ver por exemplo o sítio: http://www.budismo.com - Acesso em : 30 de julho de 2017 e o canal de vídeos no Youtube, chamado "Budismo e você" - Disponível em : https://www.youtube.com/channel/UCVmUQdxQ4QnQLhklcRBsB6Q; Acesso em : 30 de julho de 2017.

${ }^{6}$ Tal assertiva é, também, um posicionamento político da HBS do Brasil, pois a difere de outras escolas que se intitulam como "filosofia de vida", além de posicioná-la diante do próprio Estado como uma instituição religiosa.
} 
associadas a tal imersão em um contexto sociocultural específico, tornando a religião acessível e visível para os brasileiros.

Tais movimentos, denominados pela própria HBS como "práticas de expansão do Sutra Lótus", têm o intuito deliberado de converter novos fiéis para a religião, cuja eficiência pode ser notada, já que, até algumas décadas, era incomum ver adeptos não decasséguis (com ascendência nipônica) nas cerimônias. Tal questão, percebida primariamente com a observação de campo, torna-se muito evidente e visível fotograficamente com a análise cuidadosa das imagens, que mostram não apenas a presença de fiéis, mas de um número considerável de sacerdotes sem ascendência nipônica, como o próprio Correia Odoshi.

\section{UM DUPLO ARQUIVO OU DEVOLVER A IMAGEM}

Ao pensar a HBS do Brasil como uma religião que quer ser vista pelos brasileiros, e que, para tanto, faz uso de diversos meios audiovisuais para isso, é fundamental lembrar que a minha inserção em campo, através do Correia Odoshi, sempre se deu portando uma máquina fotográfica, sendo apresentado como um fotógrafo para os membros da comunidade. Surge uma segunda questão referente ao acervo de imagens produzidas na experiência etnográfica que, minimamente, tensiona a questão da "propriedade" das fotografias.

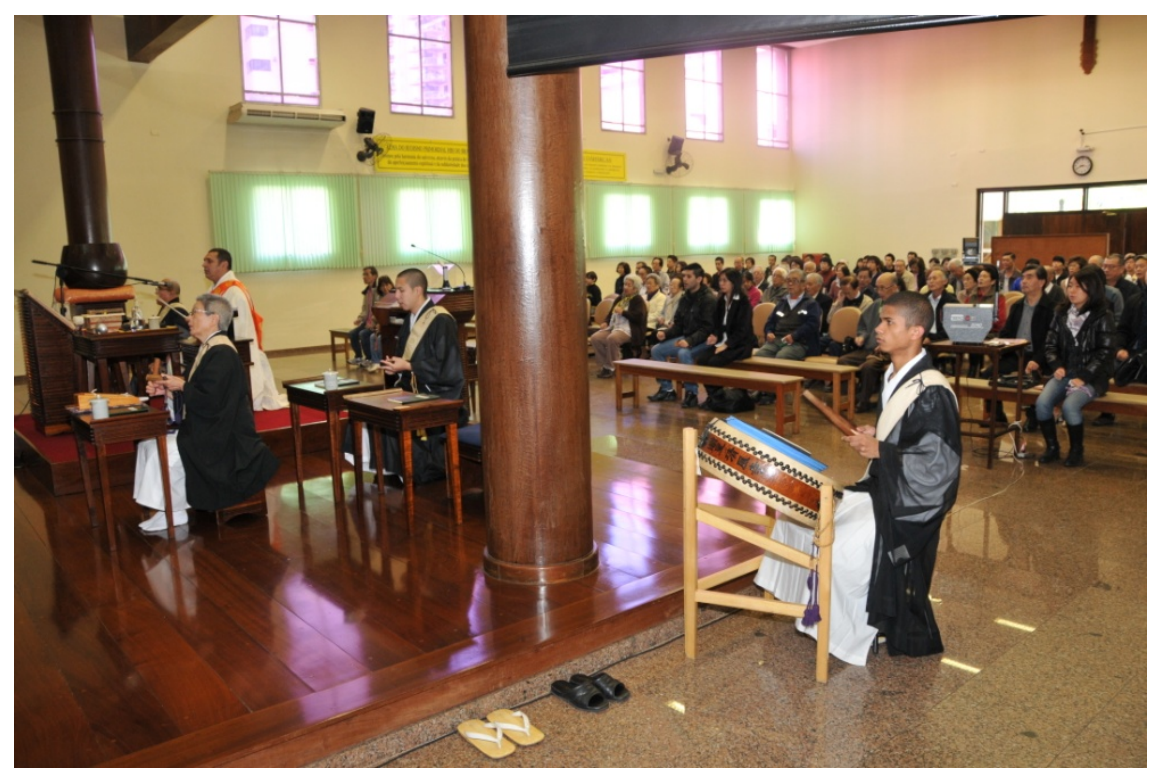

Imagem 03: Vista frontal do Hondo (nave do templo) na Catedral Nikkyoji, em São Paulo. Na parte esquerda da fotografia, é possível notar o Correia Odoshi, que porta um kesa (faixa sacerdotal) de cor laranja, celebrando um culto matinal. Na parte direita da imagem, tocando o taiko (tambor japonês), está o sacerdote Kyougyou Amaral, na época o mais jovem monge budista do país. 
Elenco uma situação exemplar que aconteceu em campo, no final da viagem pela Índia, mais especificamente na noite de 20 de maio de 2014, quando a caravana passava por Kapilavastu, no local onde, segundo o mito budista, o pai de Siddharta Gautama -, considerado por todas as escolas como o fundador da religião e também conhecido como Buda Histórico -, possuía um feudo. Após visitar tal local, já no final do dia, entrei no aposento que ocupava e dividia com o Arcebispo Correia e o seu filho7. Neste momento, o Odoshi me pediu que transferisse todas as imagens que havia produzido, durante a peregrinação, para o seu HD externo, para que ele também tivesse as fotografias, que seriam mostradas "de vez em quando para os fiéis", "colocadas no site e na revista Lótus" e "guardadas para o arquivo da HBS".

Tal pedido, aparentemente normal, causou grande constrangimento para mim no momento em que foi realizado. Naquela hora, pensei algo como: "mas as fotos são minhas, eu sou o fotógrafo e elas me pertencem", tendo respondido: "são muitas imagens, e bem grandes, vai demorar muito para transferi-las para o HD". No que, prontamente, recebi uma tréplica do Odoshi: "sem problemas! É um HD muito rápido, que comprei exatamente pra isso".

Então, ainda inquieto, mas tentando não expressar tal sentimento, peguei o HD externo e copiei todos os arquivos, em formato RAW ${ }^{8}$. Ao pensar analiticamente, após três anos da peregrinação, esse pedido e reação a ele são representativos das diversas potencialidades que um acervo fotográfico possui, dentre elas, as de servirem como forma de registro e memória tanto para uma comunidade específica, quanto para o fotógrafoantropólogo. Neste sentido, é necessário mencionar que, posteriormente, muitos outros sacerdotes e fiéis vieram solicitar as cópias das fotos, mostrando que existe um conjunto de relações que vão além da autoria, isto é, do selo de fotógrafo-oficial da caravana.

Phillipe Dubois elenca, no livro "O Ato fotográfico e outros ensaios" (1994), que a fotografia teve três fases principais: na primeira, foi tratada como espelho do real (em um discurso da mimese, da verossimilhança); na segunda, foi vista "como transformação do real", no qual a tentativa era demonstrar que a imagem fotográfica não é um espelho neutro, mas

\footnotetext{
${ }^{7}$ Os sacerdotes e sacerdotisas da HBS, diferentemente de algumas tradições budistas celibatárias, podem se casar e constituir família. Na viagem em questão, sempre dividia a morada com o Correia Odoshi e o seu filho, Yuudi Correia, que também se tornou um sacerdote, pouco depois da peregrinação.

${ }^{8} \mathrm{O}$ formato "RAW", que em inglês significa "cru", consiste em imagens geradas por câmeras digitais com tecnologia mais recente. Quando uma imagem é feita em RAW, ela carrega toda a gama de detalhes, de cores e de iluminação que as fotografias em outras configurações, como o "jpeg" ou o "jpg", não possibilitam, visto que estes formatos desprezam algumas informações para gerar uma imagem otimizada e mais leve. $O$ arquivo em "RAW" é usualmente nomeado, neste sentido, como o "negativo digital", em analogia aos negativos gerados pelas máquinas fotográficas analógicas, por possuírem todas as "informações" visuais do "momento" fotografado.
} 
"um instrumento de transposição, de interpretação e até de transformação do real (como a língua), culturalmente codificada"; e, depois, a fotografia foi colocada como traço de um real, com o discurso do índice e da referência, no qual se vai além da simples denúncia do "efeito do real: deve-se interrogar segundo outros termos a ontologia da imagem fotográfica" (1994, p. 26-27).

No caso do Correia Odoshi e dos sacerdotes e fiéis que me pediram as imagens, notei que a relação com a fotografia estaria associada, primariamente, a este terceiro modo, no qual ela seria capaz de provar a veracidade dos fatos, que a caravana esteve lá, em todos os locais sagrados para o Budismo, uma utilização do meio fotográfico que esteve muito presente já nas monografias de Malinowski ${ }^{9}$ e ganhou uma dimensão importante nas obras de Lévi-Strauss, como técnica de registro que acompanhava o seu caderno de campo.

Tal associação indicial da imagem fotográfica, desejada ${ }^{10}$ por Correia Odoshi para provar e lembrar que a caravana "esteve lá", está relacionada diretamente com o poder mnemônico da imagem, ligada ao passado inalcançável revelado no presente. Para Dubois, é "essa obsessão que faz de qualquer foto o equivalente visual exato da lembrança. Uma foto é sempre uma imagem mental, nossa memória só é feita de fotografias" (1994, p. 314).

Neste sentido, autores como Ricoeur (2004), Bobbio (1997) e Berger (1999) sugerem, ainda, que existe uma relação entre imaginação e lembrança, que seriam os componentes da memória. No caso das fotografias, tal análise é útil para pensar que, extrapolando o âmbito material do suporte físico, a relação entre a imaginação e a lembrança se faz, ainda, com a reconstrução da identidade:

"Se o mundo do futuro se abre para a imaginação, mas não nos pertence mais, o mundo do passado é aquele no qual, recorrendo a nossas lembranças, podemos buscar refúgio dentro de nós mesmos, debruçar-nos sobre nós mesmos e nele reconstruir nossa identidade; um mundo que se formou e se revelou na série ininterrupta de nossos atos durante a vida, encadeados uns aos outros, um mundo que nos julgou, nos absolveu e nos condenou para depois, uma vez cumprido o percurso de nossa vida, tentarmos fazer um balanço final... O tempo da memória segue um caminho inverso ao do tempo real: quanto mais vivas as lembranças que vêm à tona de nossas recordações, mais remoto é o tempo em que os fatos ocorreram" (BOBBIO, 1997, p.55).

Assim, ao refletir sobre o pedido do Correia Odoshi, a questão associada com o desejo do arquivo imagético, capaz de evocar lembranças e provar que a caravana visitou todos os locais sagrados para a religião, levanta outra questão capitular acerca da subjetividade da autoria das imagens. Talvez o meu incômodo a esta solicitação faça

\footnotetext{
${ }^{9}$ Aqui, o artigo "Ver e Dizer na tradição etnográfica. Bronislaw Malinowski e a Fotografia", de Etienne Samain (1995b), é uma importante contribuição para perceber o panorama da utilização da fotografia na Antropologia do início do século XX.

${ }^{10}$ Sobre a questão do desejo pela (e da) imagem, recomendo os artigos "Imagem, mímesis \& méthexis", de Jean Luc-Nancy (2015) e "O que as imagens realmente querem?", de W. J. T. Mitchell (2015).
} 
referência ao fato de que, em uma primeira reflexão, eu havia tirado as fotografias que correspondiam à minha demanda de fotógrafo-antropólogo. Ao me deparar com o pedido do Odoshi, para que passasse a ele o arquivo visual bruto, sem nenhuma seleção prévia, houve um desconforto inicial que gerou importantes análises.

Ao compartilhar o acervo da viagem, fato que não ocorreu com as imagens produzidas nas pesquisas etnográficas realizadas no Brasil, percebi que a minha presença no campo estabelecia relações complexas, que não atendiam apenas aos meus interesses de pesquisador. Durante a viagem, por exemplo, fui nomeado como fotógrafo-oficial, também por Correia Odoshi, e assim era apresentado para os demais membros da caravana e para os sacerdotes e fiéis japoneses. Contudo, esta dádiva, ao mesmo tempo em que me colocava em um lugar do encontro etnográfico privilegiado, em um espaço de intensa relação entre intersubjetividades que me permitia acessar e fotografar todos os momentos e eventos, laicos ou rituais, também me solicitava uma contrapartida.

Desta maneira, eu me inseria dentro de parâmetros que não estavam apenas sob o meu controle, jogando (no bom sentido do termo), também, com o que os outros esperavam de mim, tendo a responsabilidade de retratar todos os eventos importantes da peregrinação, o que pode ser considerado como uma contradádiva, no sentido proposto por Mauss (1988 [1925]).

Tal importância da devolução das imagens para a comunidade já foi estudada por diversos autores, como, por exemplo, Kim (2015), que submeteu a sua produção fotográfica aos seus interlocutores, cadeirantes jogadores de rúgbi, em um trabalho de coprodução no qual os retratados não são meros objetos da pesquisa; e Copque (2015), que fotografou presidiários com o intuito de entender que tipo de tatuagem eles faziam, garantindo o anonimato dos rostos e corpos e discutindo as imagens com os pesquisados, estabelecendo uma relação de confiança e um diálogo pautado no "deixe eu ver como ficou!" ou o "apague essa".

Esta contradádiva pode ser bem exemplificada por outro episódio, também em Kapilavastu, no qual, acometido por uma infecção alimentar aparentemente grave, por um instante me recusei a sair do ônibus da HBS para fotografar tal local sagrado do Budismo. Neste momento, recebi o incentivo de vários caravanistas para que saísse do veículo e fotografasse o local, assim como obtive ajuda para carregar uma pesada mochila, que continha todos os equipamentos fotográficos. 


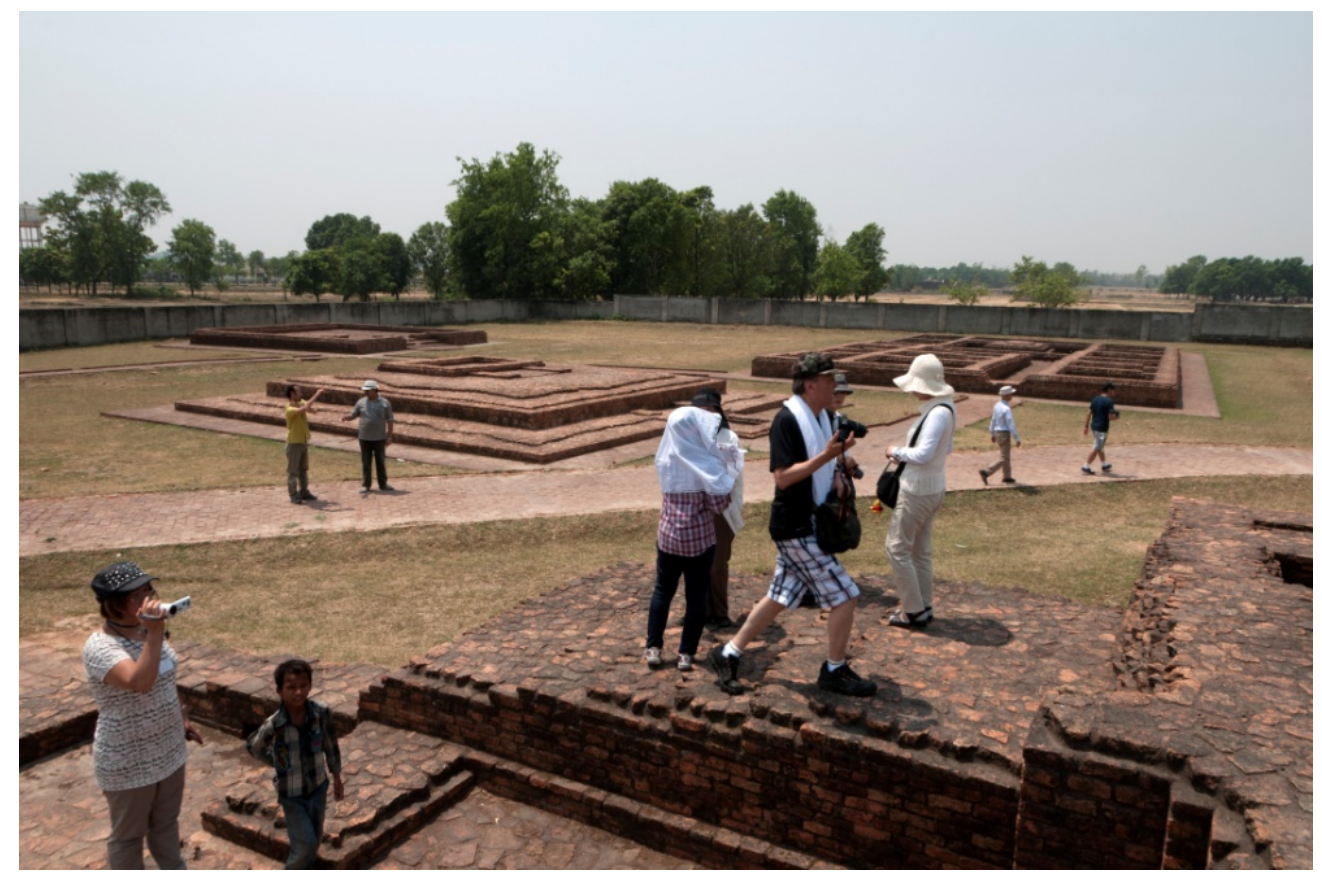

Imagem 4: Kapilavastu, local onde, segundo a mitologia budista, ficava o feudo do pai do Buda Histórico.

Mesmo me sentindo incomodado com o fato de ter que fotografar em todas as ocasiões da pesquisa de campo, algumas vezes a contragosto, realizar tais reflexões sobre estes eventos são fundamentais para pensar na experiência etnográfica. Assim, percebo que, além de me verem como um fotógrafo, que possuía uma função dentro da comunidade ao ser o responsável por registrar imageticamente todos os momentos de uma viagem única -, que, embora ocorra trienalmente, nunca reúne o mesmo grupo de sacerdotes e fiéis -, a caravana não me via simplesmente como um outsider, mas quase como um fiel convertido, em uma relação que questiona uma distinção antropológica clássica entre sujeito e objeto.

Aqui, é possível pensar que a minha função como fotógrafo-oficial, estabelecida na viagem com a HBS do Brasil, mostra que eu era visto não como um forasteiro, mas como alguém que compunha tal caravana religiosa, o fotógrafo. Para tanto, além de ter a liberdade e a autorização de utilizar as imagens sem sofrer quaisquer imposições ou censuras, eu precisava, em contrapartida, cumprir determinadas demandas que também possuem um determinado lugar e alguns custos.

Dessa forma, ainda é necessário mencionar que, após o período da viagem, sou frequentemente chamado para participar de grandes eventos nos templos da HBS do Brasil, em especial no Templo Rentokuji, localizado em Campinas, cidade onde resido atualmente. Implicitamente, os fiéis e sacerdotes esperam que eu continue cumprindo com a minha função, sendo que, normalmente, não posso ir apenas para observar e participar das cerimônias, mas para, também, fotografá-las. 


\section{CONSIDERAÇ̄ES FINAIS}

Ao analisar esta dupla função da fotografia na pesquisa por mim realizada junto à comunidade HBS do Brasil - como método de inserção e aceitação no campo etnográfico e como fonte de rememoração pós-campo, tanto para mim quanto para a Honmon Butsuryushu - e longe de querer esgotar as possibilidades de análises e os usos diversos da imagem fotográfica na Antropologia, é fundamental sublinhar uma importante questão, que foi levantada por Georges-Didi-Huberman (2015b, p. 205-206), quando o mesmo afirma que, ao dizermos que "tiramos uma foto", precisamos saber se "não é necessário devolvê-la a quem é de direito"?

Desta forma, o presente trabalho busca tensionar a noção de posse das imagens, e, na mesma direção, elencar a necessidade ética da sua restituição, não estabelecendo um direito privado, mas enfatizando a qualidade de coprodução deste acervo fotográfico ${ }^{11}$.

Se, para mim, o ato de olhar com cuidado um arquivo fotográfico adiciona uma "dimensão suplementar de ordem moral destinada a reforçar a credibilidade e a confiabilidade do testemunho" (RICOEUR, 2004 p. 170-171), as fotografias e o arquivo que elas compõem para mim (sendo distinto da forma como foi arquivada, por exemplo, pelo Correia Odoshi) consistem precisamente nas minhas testemunhas oculares, sendo que foi a partir delas que pude começar a escrever (através da rememoração visual dos acontecimentos), como se as imagens tivessem o poder mágico de revitalizar o tempo, o espaço e os personagens envolvidos na trama fotográfica.

Por outro lado, é necessário pensar nas relações que o ato fotográfico estabeleceu no meu campo de pesquisa. Pensar, assim, as fotografias coproduzidas com a HBS do Brasil como alicerces da relação entre fotógrafo-antropólogo e comunidade, um bem comum, uma dádiva e uma contradádiva (MAUSS, 1988), pois, ao mesmo tempo em que me ега possibilitado fotografar sem quaisquer restrições todos os eventos e rituais da HBS, tanto no Brasil quanto no Japão, Índia e Nepal, tive que retribuir tal privilégio, ao compartilhar as imagens produzidas.

Neste sentido, ressalto ainda que seria inviável, para mim, realizar tal imersão etnográfica sem a fotografia, porque, primariamente, eu era um fotógrafo antes de ser um antropólogo, algo que me tornei, aos poucos, no decorrer da pesquisa. Tal relação estabeleceu e fortaleceu, de fato, os meus laços com os interlocutores, gerando um

\footnotetext{
${ }^{11}$ Segundo Georges Didi-Huberman, "a grande virtude desse raciocínio é manter o ato de restituição fora de toda atribuição tal ou qual: restituir não é atribuir alguma coisa a alguém para que ele anexe e se privilegie [e sobre ele prevaleça] um direito privado. A restituição não implica nem anexação nem a aquisição de propriedade. Desde que uma coisa pertence a um proprietário, ele não é mais restituído" (2015b, p. 210).
} 
sentimento de pertencimento e abalando um possível dualismo entre sujeito e objeto de pesquisa.

\section{REFERÊNCIAS}

BARBOSA, Andrea. Significados e sentidos em textos e imagens. In: BARBOSA, Andréa; CUNHA, Edgar Teodoro da; HIKIJI, Rose Satiko (org.). Imagem-conhecimento. Campinas: Papirus, 2009, p. 71-84.

BATESON, Gregory; MEAD,Margaret. Balinese Character: A Photographic Analysis. New York: Academy of Sciences, 1942.

BELTING, Hans. Por uma antropologia da imagem. Concinnitas, v. 01, ano 06, n. 08, p. 64-78, 2005.

BERGSON, Henri. Matéria e Memória: ensaio sobre a relação do corpo com o espírito. São Paulo: Martins Fontes, 1999 [original francês: 1939].

BOBBI0, Norberto. 0 Tempo da Memória. De senectute e outros escritos autobiográficos. Rio de Janeiro: Campus, 1997.

BRANDÃO, Carlos Rodrigues. Escrito com o olho. Revista de Antropologia Visual, v. 1, n. set/out, p. 127, 2005.

COPQUE, Bárbara. Fotografar: expor (e se expor) - a utilização da fotografia no contexto da violência. In: CAIUBY NOVAES, Sylvia (org.). Entre arte e ciência: a fotografia na antropologia. São Paulo: EdUSP, 2015, p. 71-92.

DIDI-HUBERMAN, Georges. Devolver uma imagem. In: ALLOA, Emmanuel (org.). Pensar a Imagem. São Paulo: Autentica, 2015, p. 205-226.

DUBOIS, 1994. 0 Ato Fotográfico e Outros Ensaios. Campinas: Papirus, 1994.

GELL, Alfred. Art and Agency: An Anthropological Theory. Oxford: Clarendon, 1998.

GOODY, Jack. Domesticação do Pensamento Selvagem. Lisboa: Presença, 1988.

INGOLD, Tim. Redrawing Anthropology: materials, movements, lines. Londres: Routledge, 2011. Making: Anthropology, Archaeology, Art and Architecture. Londres: Routledge, 2013.

\section{Vozes, 2015.} Estar vivo: ensaios sobre movimento, conhecimento e descrição. Rio de Janeiro: Editora

KIM, Joon Ho. 0 rúgbi em cadeira de rodas: um breve ensaio sobre a (des)construção da imagem da deficiência física. In: CAIUBY NOVAES, Sylvia (org.). Entre arte e ciência: a fotografia na antropologia. São Paulo: EdUSP, 2015, 43-70.

LÉVI-STRAUSS, C. 0 Pensamento Selvagem. Campinas: Papirus, 2006 [original francês: 1962]. 
MALINOWSKI, Bronislaw. Argonautas do pacifico ocidental: Um relato do empreendimento e da aventura dos nativos nos arquipélagos da Nova Guiné melanésia. São Paulo: Abril Cultural, 1976 [original inglês: 1922].

MAUSS, Marcel. Ensaio sobre a dádiva. São Paulo: Edições 70: 1988 [original francês: 1925]

RICOEUR, Paul. A memória, a história, o esquecimento. Campinas: Editora Unicamp, 2004.

SAMAIN, Etienne (org.). 0 Fotográfico. São Paulo: Editora Senac e Editora Hucitec, 2005.

SAMAIN, Etienne. Como pensam as imagens. Campinas, SP: Editora da Unicamp, 2012.

Os riscos do texto e da imagem: Em torno de Balinese Character (1942) de Gregory

Bateson e Margaret Mead. Significação. Revista Brasileira de Semiótica, n. 14, p. 63-88, 2000.

. Ver e Dizer na tradição etnográfica. Bronislaw Malinowski e a Fotografia. Horizontes

Antropológicos, ano 01, n. 02, jul./set, p. 23-60, 1995. 